Contents lists available at Journal Redwhitepress
Journal of Educational and Learning Studies
ISSN: 2655-2760 (Print) ISSN: 2655-2779 (Electronic)
Journal homepage: http://journal.redwhitepress.com/index.php/iles

\title{
Development of the Guidelines Module in Counseling to Prepare Young Women on Facing Physical Change
}

\author{
Amelia Safitri ${ }^{1}$, Mudjiran $^{2}$, Alizamar $^{3}$ \\ ${ }^{123}$ Universitas Negeri Padang
}

\begin{tabular}{l} 
Article Info \\
\hline Article history: \\
Received Dec $28^{\text {th }}, 2018$ \\
Revised Feb $27^{\text {th }}, 2019$ \\
Accepted Apr $4^{\text {th }}, 2019$ \\
\hline
\end{tabular}

\section{Keyword:}

Facing Physical Change Teenage Girl

Information Service

Module

\begin{abstract}
Self-preparation in dealing with physical changes is a necessity for young women, and lack of preparation will lead to several problems such as; anxiety, fear, timidity, sleeplessness, loss of appetite, and disruption of adult development. Self-preparation can be improved through information services provided by counselors using appropriate media and materials. The ADDIE model was used in this research and six experts were employed as subjects to validate service guidelines based on the display of laid down principles. Three counselors were on standby to test the use of the guidelines, and a total of thirty students were tested. The descriptive and inferential analysis with the Kendall coefficient (W) test were used to perform the examination. Therefore the result of the study shows that the prototype information service module can be used to prepare young women for physical changes during puberty.
\end{abstract}

(C) 2019 The Authors. Published by Redwhitepress.

This is an open access article under the CC BY-NC-SA license (https://creativecommons.org/licenses/by-nc-sa/4.0/

\section{Corresponding Author:}

Amelia Safitri,

Universitas Negeri Padang

Email: ameliasafitri04@gmail.com

\section{Introduction}

During growth and development stages, the teenager experiences many changes, both physical, cognitive, and psychosocial (Papalia, D. E, 2009). It is a period of maturation of the human reproductive organs and it is often referred to as puberty. During this period, the child's body begins to develop and experience rapid changes, including the physical which is the main characteristic of the biological process of adolescence (Soetjiningsih, 2004).

(Rogol, Clark, \& Roemmich, 2000) Stated that puberty is a relatively short period, where young people experience many physical changes, including growth, maturity, development of primary and secondary organs, as well as reproductive ability. At this time they begin to show feelings of being attracted to the opposite sex.

Several researcher shows that many problems occur during this stage and some of these include; sexuality problems, the emergence of negative feelings (stress, anxiety, worry, depression, shame, confusion), eating disorder, substance abuse (Reena, 2015; Verawaty \& Rahayu, 2011) others are; the emergence of various questions, low self-esteem, lack of confidence etc. (Al-Mighwar, 2006; Santrock, 2011).

Lutfiya (2016) reported that the readiness of teenager in dealing with menarche is usually dependent on the availability of knowledge and relevant information. Poor understanding of this situation results in inadequate preparation and inability to manage the physical and psychological effects of this growth stage (Herwati, Wiyono. 2017). 
According to Soetjiningsih (2004), several factors such as customs, culture, religion, and lack of information from the right sources might affect how an individual understands the puberty stage. Based on the Meliala research (2016) 13 teenagers had inadequate knowledge, and this showed that the majority were not ready to face puberty (52.4\%). According to Noviyanti \& Sarbini (2010), the major factor that influences thisthis situation is information.

The results of the study of (Sutinah, 2010) showed that most of the teenager, about 38 (66\%) did not receive accurate knowledge of the physical changes during this growth stage. Therefore, they do not know and are not well prepared. Therefore, this is the major reasons for problems during puberty. Teenagers with proper maturity trainings feel better about facing these physical changes. However, lack of understanding affects young people during this growth phase.

(Rogol, Clark, \& Roemmich, 2000) Stated that puberty is a relatively short time, where humans experience physical changes, including growth, development of primary and secondary characteristics, and reproductive ability. At this time they begin to show feelings of being attracted to the opposite sex; more attention is given to the body to build relationship with male counterpart.

Many problems occur during puberty due to physical changes. Some find it difficult to deal with sexuality problems, there is general emergence of negative feelings (stress, worry, anxiety, depression, shame, confusion), eating disorders, substance abuse (Reena, 2015; Verawaty \& Rahayu, 2011), low self-esteem, lack of confidence, difficult to adjust to situations etc.(Al-Mighwar, 2006; Santrock, 2011).

According to Lutfiya (2016), the preparation of teenagers in dealing with menarche is influenced by the level of knowledge and the amount of relevant information. Inadequate education of young people will result in poor preparation for puberty, and this will affect their readiness for physical changes (Herwati, Wiyono. 2017).

Soetjiningsih (2004) reported that a person's lack of understanding could be caused by several factors, such as customs, culture, religion, and lack of information from the right sources. Based on the Meliala research (2016), 13 teenagers who represented the majority had less knowledge and were not ready to face puberty (52.4\%). In line with what was stated by Noviyanti \& Sarbini (2010) the factors that influence people's readiness is mainly information.

The results of the study (Sutinah, 2010) showed that most of the teenager, $38(66 \%)$ did not receive proper education on physical changes during puberty. This is the main cause of problems during this developmental phase of life. According to research, the challenges that arise in terms of physical changes are largely dependent on understanding, which influences perceptions and attitudes. Generally, the attitude often expressed by the teenagers are timidity, worriedness, anxiety about changes that occur such as breast enlargement, increase in hip size, first menstruation, weight, height, etc. pimples growth also reduce the confidence of an average teenager.

One significant way to prepare adolescents for physical changes is by providing relevant knowledge and understanding through information that is true, open, and easily obtained information. This should contain several changes experienced by young people and how to successfully survive these changes. By doing this, teenagers will optimally pass developmental tasks of physical changes.

Based on the findings described previously, the objective of this paper is the role of counselling to prepare teenager on facing physical changes. Therefore, through the research model, this objective will be fulfilled.

\section{Results and Discussions}

\section{Results}

\section{Nature of Module}

According to Russell (in Ali \& Asrori, 2004) the module is a learning package of a unit of educational material. (Mulyasa, 2005) reported it is an independent design that includes a series of well-planned and systematically produced learning experiences to help students achieve various learning goals. Moreover, (Dharma, 2008) reported that it as a tool containing materials, methods, and boundaries systematically designed to produce the expected competencies in accordance with the level of complexity.

Russell (in Ali \& Asrori, 2004) also reported the module as an educative package relating to a unit of learning material. Furthermore, (Mulyasa, 2005) reported it is a module as an independent package that includes a series of educational experiences that are planned and designed systematically to help students achieve learning goals. The same was expressed by (Dharma, 2008), the module is a tool containing materials, 
methods, boundaries, and how to evaluate designed systematically and interestingly to achieve the expected competencies in accordance with the level of complexity.

Furthermore, according to the Directorate of Vocational High School Development (Direktorat Pengembangan Sekolah Menengah Kejuruan), Modules are one form of instructional materials that are packaged intact and systematically, containing a set of planned learning experiences and are designed to help students' master more specific learning goals. Its existence will make it easier for educators to provide explanations and direction to students, and also train students to be more independent in carrying out learning activities.

Based on the description previously described, it can be concluded that it is a systematically packaged learning material directed to make students understand the learning material.

\section{Nature of Information Services Module in Counselling}

Information services enhance the transfer of knowledge with the aim of expanding individual understanding as well as create room for proper utilization of this information. (Prayitno, 2017) reported that Information services aim to provide understanding to individuals who have an interest in various things needed to undergo a desired goal or plan.

The Indonesian Guidance and Counseling Association explained that information help students receive and understand various personal, social, learning, career and positional information.

Furthermore, (Zaenal, 2012) reported that these services allow students to receive and understand ideas that used as the material for consideration in making decisions. Tohirin (2007) reported that information services mean efforts to equip students with different facets of knowledge and understanding regarding the surrounding environment and the development process of young people.

According to Tohirin (2007), it provide knowledge about various things in various ways to individuals, aiming both verbally and in writing, which is useful for daily living and development. These ideas are to be implemented by the BK counselor and followed by the students. The module was created with four parts which are useful for preparing young women for regular adolescent physical challenges. The four parts are: Physical changes, Changes in body size and proportion, primary sex changes, secondary sex changes.

\section{Nature of Teenager}

Knopka (Yusuf, 2007) reported that adolescence can be divided into (a) early adolescents: 12-15 years; (b) middle teens: 15-18 years; (c) late adolescents; 19-22 years old. Judging from this age limit, junior high school students of 12-15 years are in the early adolescent stage. The junior high school students are in the early teenage period. Early adolescence is often called puberty. It is the stage where an individual leaves childhood period and begins to enter adulthood. Therefore the teenage period can be said to be a transition period.

According to Battles \& Wiener, (2002), it is a time of behavioral experimentation and risk-taking, where the youths work to increasing independence. The description above can be interpreted that puberty is a period when young people are happy to experiment and try new things. Teenagers are generally happy to work independently without thinking about the impact.

Puberty is defined as the period of developmental transition between childhood and adulthood which includes changes in physical, cognitive and psychosocial, (Papalia, 2009; Santrock, 2011). The following physical development aspects of adolescents that command more attention are noticeable; height and weight, the growth of body frame, reproductive function, and hormonal changes. The impact of this physical change is greater for a teenager than for young men, (Al-Mighwar, 2006; Reena, 2015).

\section{Nature of Physical Change}

(Fatimah, 2010) proposed that developmental aspects of adolescence are a) physical development, $b$ ) cognitivegrowth, c) psychosocial development, (Jahja, Y; Syamsussabri, 2013). If any aspect experiences obstacles, it will affect the development of others.

(Fatimah, 2010) States that physical growth is a change that takes place physically and it is the primary symptom in adolescent growth. The human body is a complex and fantastic system. As stated earlier, during 
puberty, the whole body undergoes changes, both on the outside and on the inside of the body. These changes are crucial for the subsequent development of sexual behaviour.

These physical developments are evident in the early teens. (Hurlock, 2002) reported four important physical changes that occur during rapid growth in adolescents, these developments includes: a) changes in body size, $b$ ) changes in body proportions, c) emergence of primary sex traits, and d) traits of sex secondary sex. Physical development in young people occurs both internally and externally. Internal changes are growth that occurs in the body of adolescents (body organs) which later will, in turn, affect the personality of the teenagers. These changes occur in the digestive system, circulatory system, respiratory system, endocrine system, and body tissues. External changes, on the other hand, are rapid growths that occur in the body of adolescents, which can be seen in the physical outside the body of the child. These changes are as follow; height, weight, body proportions, primary sex characteristics, and secondary sex characteristics.

$\square$ zdemir, A., Utkualp, N., \& Pallo $\square$, (2016) reported some physical developments that occur during puberty and it include: a) physical growth and sexual development, b) increase in height and weight (increase in body height and weight), c) muscle development (development of body muscles), d) organ growth (body organ growth.

During puberty, physical changes will increasingly reach an individual balance. At the end, the body size of a teenager has reached its final form, and the reproductive system has attained physiological maturity. As a result of this process in the reproductive system, a teenager is able to carry out his procreation. However, this does not mean that teenagers are able to reproduce safely. Research explains that the module can be used to prepare students to face physical changes.

\section{Framework for Developing Counselling Modules to Prepare Teenager in Facing Physical Change}

Fig 1 explained that teenagers with poor preparation for puberty require information services. Counselling is needed to enhance understanding and prevent problems of physical changes. Therefore, the research was developed through the ADDIE model (analysis, design, development, implementation, and evaluation). This model is used because it is simple, easy to apply and it is quite accurate in its feasibility and suitability.

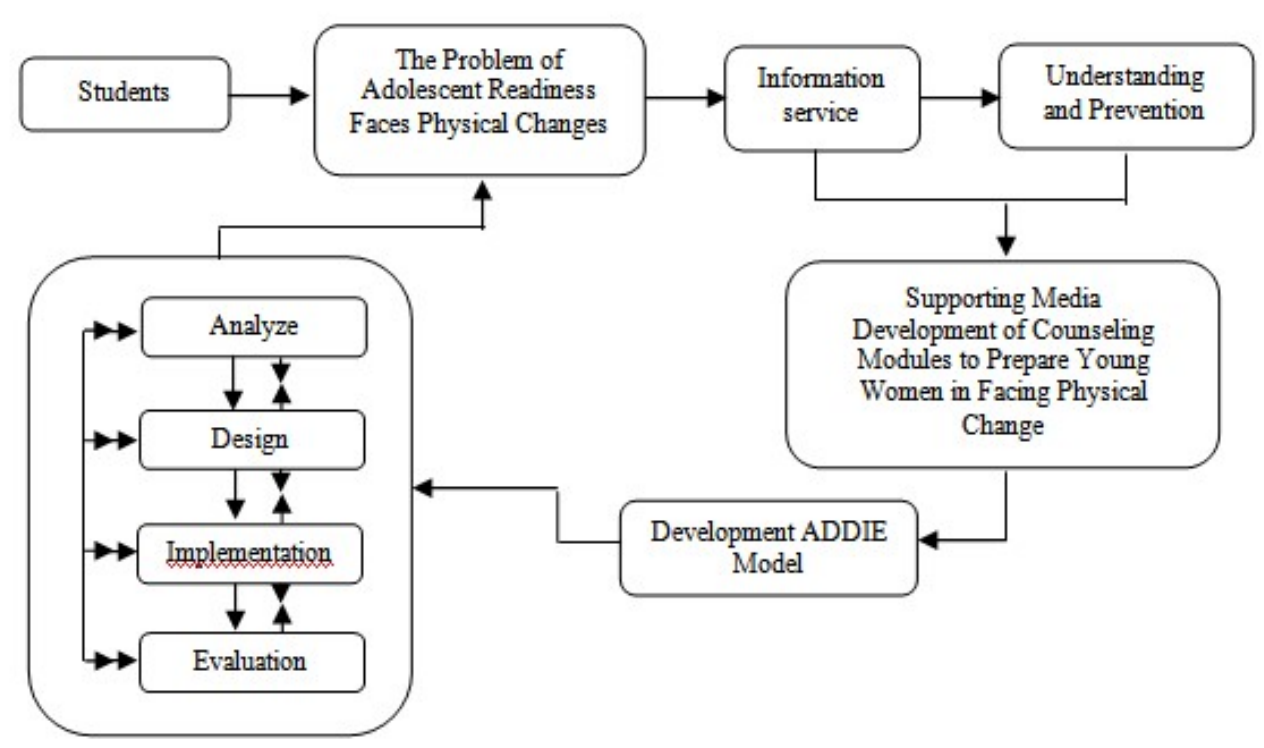

Figure 1: ADDIE design for Development of Counseling Model 


\section{Implications}

As explained in the Ministry of National Education (2008: 192), the rationale for organizing guidance and counseling in schools is not just on the existence of a legal basis (legislation), It also involves efforts to facilitate the counselor to be able to develop the teenager's ability to achieve developmental tasks such as physical, emotional, intellectual, social and moral-spiritual aspects. Therefore this conceptual idea of thinking related to "the development of counseling modules to prepare teenager in facing physical change" is expected to provide some contribution in guidance and counseling which includes:

1. Theoretical Implications for Counselors

Through this idea, the benefits of theoretical implications for counselors are expected to contribute to the theoretical usefulness of counselors, both in terms of discourse and reference studies in counseling services. The counseling model will provide the benefits of guidance and counseling services.

2. Practical Implications for Counselors

The benefits of practical implications for counselors will enhance professionalism in providing counseling services and proper application of theses counseling modules to prepare teenager to face physical developments. Therefore, the practical use of this counseling module will provide an example of counseling to prepare teenager to face physical changes.

3. Practical Implications for Students

The counseling module is also expected to provide benefits for the teenager in preparing themselves for physical changes such as development in form, proportion, primary sex, and secondary sex to enhance teens preparation for physical changes and are able to achieve optimal development.

\section{Conclusions}

According to the research, the role of the counselling module is to prepare teenagers ahead of the physical changes during puberty. The ADDIE model was used in this research to prepare adolescents for developments into maturity.

\section{Acknowledgments}

Acknowledge anyone who has helped you with the study, including: Researchers who supplied materials, reagents, or computer programs; anyone who helped with the writing or English, or offeredcritical comments about the content, or anyone who provided technical help. State why people have been acknowledged and ask their permission. Acknowledge sources of funding, including any grant or reference numbers. Please avoid apologize for doing a poor job of presenting the manuscript.

\section{References}

Al-Mighwar, M. (2006). Psikologi Remaja: Petunjuk bagi guru dan orangtua. Bandung: Pustaka Setia. Ali, M \& Asrori, M. (2004). Psikologi Remaja: Perkembangan peserta didik. Jakarta. Bumi Aksara.

Battles, H. B. \& Wiener, L. S. (2002). From Adolescence Through Young Adulthood: psychological adjustment associated with long-term survival of HIV. Journal of Adolescent Health, 30: 161-168.

Dharma, S. (2008). Penulisan Modul, Kopetensi Penelitian, dan Pengembangan. Jakarta: Departemen Pendidikan Nasional.

Fatimah, E. (2010). Psikologi Perkembangan (Perkembangan Peserta Didik). Bandung: Pustaka Setia.

Herwati, I., Wiyono, J., \& W., R. C. A. (2017). Hubungan Pengetahuan Remaja Putri Tentang Perubahan Fisik Pada Masa Pubertas Dengan Tingkat Stres. Nursing News, 2(1), 511-523. https://doi.org/10.1021/BC049898Y

Hurlock, E. B. (2002). Psikologi Perkembangan: Suatu pendekatan sepanjang rentang ehidupan, Edisi 5. Alih bahasa: Istiwidayanti dan Soedjarwo. Jakarta: Erlangga.

Jahja, Y. (2013). Psikologi Perkembangan. Jakarta: Kencana Prenada Media Group.

Lutfiya, I. (2016). Analisis Kesiapan Siswi Sekolah Dasar dalam Menghadapi Menarche. Biometrika Dan Kependudukan, 135-145. https://doi.org/10.1007/s00228-013-1600-y

Monks, F,J., \& Knoers, A. M. . (2001). Psikologi Perkembangan (Pengantar dalam Berbagai Bagiannya). Yogyakarta: Gadjah Mada University Press.

Mulyasa, E. (2005). Kurikulum Berbasis Kompetensi: Konsep, karakteristik, dan implementasi. Bandung: Remaja Rosdakarya.

Noviyanti, R. D., \& Sarbini, D. (2010). Hubungan Status Gizi Dengan Status Imunitas Anak Balita Di RW 
VII Kelurahan Sewu, Kecamatan Jebres, Kota Surakarta, Jurnal Kes.

Papalia, D. E, O. \& F. (2009). Human Development, Edisi 10 buku 2. Jakarta: Salemba Humanika.

Prayitno. (2017). Konseling Profesional yang Berhasil. Depok: Rajagrafindo persada.

Reena, M. (2015). Psychological Changes During Puberty -Adolescent School Girls. Universal Journal of Psychology, 3(3), 65-68. https://doi.org/10.13189/ujp.2015.030301

Rogol, A. D., Clark, P. A., \& Roemmich, J. N. (2000). Growth and pubertal development in children and adolescents: Effects of diet and physical activity. In American Journal of Clinical Nutrition (Vol. 72). https://doi.org/10.1093/ajcn/72.2.521S

Santrock, J. W. (2011). Educational psychology 5 edition. Newyork: McGraw- Hill. E books. Soetjiningsih. (2004). Tumbuh Kembang Remaja dan Permasalahannya. Jakarta: Sagung Seto.

Sutinah, D. \&. (2010). Gambaran Tingkat Pengetahuan Remaja Putri Kelas Vii Tentang Perubahan Fisik Masa Pubertas Di Smp Muhammadiyah 1 Sendangadi Mlati, Sleman, Yogyakarta.

Syamsussabri, M. (2013). Konsep dasar pertumbuhan dan perkembangan peserta didik. Perkembangan Peserta Didik, 1(1), 1-9. https://doi.org/10.1109/MEMSYS.2006.1627944

Tohirin. (2007). Bimbingan Konseling di Sekolah dan Madrasah. Jakarta: Raja Grafindo Persada.

Verawaty \& Rahayu. (2011). Menjaga dan Merawat Kesehatan Seksual Pria. Bandung: Grafindo Media Pratama.

Yusuf, S. (2007). Psikologi Perembangan Anak dan Remaja. Bandung: Remaja Rosdakarya.

Zaenal, A. (2012). khtisar Bimbingan \& Konseling di Sekolah. Bandung. Yrama widya.

$\square$ zdemir, A., Utkualp, N., \& Pallo $\square$, A. (n.d.). Physical and Psychosocial Effects of the Changes in Adolescence Period. International Journal of Caring Sciences, 9 (2): 717-723. 